\title{
РЕАЛЬНЫЕ И РИТУАЛЬНЫЕ ФОРМЫ ОСВОЕНИЯ ПРИРОДЫ У БАТАКОВ ИНДОНЕЗИИ Е.В. Ревуненкова
}

Музей антропологии и этнографии им. Петра Великого, Санкт-Петербург, Россия

Эл.noчma: evrevu@gmail.com

Статья потупила в редакцию 19.06.2016; принята к печати 02.08.2016

В традиционном укладе жизни хозяйственная и обрядовая деятельность выступают в единстве, отражая взаимоотношения между человеком и природой в целом, как это показывает неразрывная связь практической, ритуальной и культурно-символической деятельности, относящейся к возделыванию риса и строительству традиционного жилого дома у батаков Индонезии. Ключевье слова: батаки, рис, дом, человек, природа.

\section{ACTUAL AND RITUAL FORMS OF COPING WITH NATURE BY BATAK PEOPLE IN INDONESIA Ye.V. Revunenkova \\ Peter the Great Museum of Anthropology and Ethnography, Saint Petersburg, Russia E-mail:evrevu@gmail.com}

Traditional lifestyle combines economic and ritual activities in a way reflecting the relationships between humans and their natural environment as it is seen in the intimate relationships between practical, ceremonial and symbolic aspects of rice culturing and house building practiced by Batak people in Indonesia

Keywords: Batak people, rice, house, humans, nature.

\section{Введение: кто такие батаки}

В статье пойдет речь о способах освоения природы, связанных с возделыванием риса и строительством традиционных жилищ, у обитателей высокогорных районов северно-западной Суматры (Индонезия) - у батаков.

Батаки, численность которых составляет около 6 млн человек, живут на обширных плоскогорьях вокруг громадного горного озера Тоба, имеющего вулканическое происхождение. Они делятся на несколько этнических групп, наиболее крупными из которых являются тоба (около 2 млн), населяющие область к югу от озера Тоба, и каро (около 700 тыс.), живущие к северу от него. Батаки, особенно тоба, являются одним из социально-активных и подвижных народов Индонезии, внесших большой вклад в развитие культуры и литературы этой страны. Батакская интеллигенция давно составляет большой процент среди профессиональных деятелей самого высокого ранга - ученых, врачей, священников, политиков, писателей. Некоторые из них приобрели мировую известность, например, поэт Ситор Ситуморанг (1923-2014), произведения которого переведены на ряд европейских языков, в том числе и на русский. Выдающийся политический деятель, батак по происхождению, Адам Малик (1917-1984), занимавший разные самые высокие политические и дипломатические посты в течение четырех десятилетий - сразу после провозглашения независимости Индонезии (1945 г.) и вплоть до своей кончины, - был назначен в 1959 г. послом Индонезии в СССР. Помимо политической, дипломатической и журналистской деятельности он активно занимался изучением культуры, собирал этнографические коллекции и произведения искусства. В настоящее время в доме Адама Малика в Джакарте находится музей, носящий его имя, в числе коллекций которого имеется обширное собрание предметов культуры и быта батаков, много картин различных художников и, что особенно поражает, большое собрание русских икон. Многие батакские студенты и будущие ученые учились и учатся в университетах Европы, США, до 1965 г. и в России, в основном в Москве и Ленинграде. Что касается Индонезии, то большая батакская община имеется в столице - Джакарте и других городах. В Медане - самом крупном городе Суматры с очень пестрым этническим составом - батаки являются лидирующим этносом, а сам город в настоящее время является главным центром изучения батакской культуры, хотя географически он находится за пределами основного района расселения этого народа. Но батаки, живущие в крупных городах, поддерживают постоянные связи со своими соплеменниками и по мере возможности вкладывают средства в сохранение наследия традиционной культуры [28, с. 246-247].

При том, какую роль играют батаки в развитии современной культурной и политической жизни Индонезии, трудно представить, что еще немногим более 100 лет назад у них была репутация воинственных дикарей, практиковавших человеческие жертвоприношения и охоту за головами. Российский читатель мог узнать об этом из журналов и газет, нередко перепечатывавших статьи из иностранных изданий об экзотических странах и народах. Так, в 1826 г. в журнале «Северный архив» появилась заметка «Людоеды и поклонники крокодилов на Суматре», одно название которой красноречиво говорит о ее содержании. Это был пересказ сочинения Дж. Андерсе- 
на - служащего администрации на острове Пинанг (современная Малайзия) - «Экспедиция к восточному берегу Суматры в 1823 году». Одновременно со статьями и заметками подобного рода и в европейской, и в российской печати первой половины XIX в. встречалось немало материалов, которые объективно освещали специфику архаичной культуры народа, сочетающей в себе черты, способные вызвать у современного человека как абсолютное неприятие, так и восхищение. Восхищение вызывают, например, жреческие рукописные книги, высочайшие образцы резной деревянной скульптуры, ткачества, традиционных жилищ. Все это наследие сохраняется и в настоящее время, во многом благодаря поддержке тех представителей батакского народа, которые покинули землю своих предков, но не теряют постоянной связи с ней [28, с. 242-248].

\section{Батаки и рис}

Одной из основных жизненных ценностей у батаков, как и большинства народов Индонезии (и всей Юго-Восточной и Южной Азии), является рис - самый древний пищевой злак, по распространенности занимающий второе место в мире после пшеницы, а по урожайности - первое. Рис в этом обширном регионе является не просто основной пищей или синонимом пищи вообще, это и средоточие основной деятельности населяющих его народов, символ жизни, благополучия, изобилия. В какой-то степени значение риса можно сравнить со значением хлеба в русском крестьянском хозяйстве в XIX-XX вв. Рисоводы Индонезии не разделяют в своем сознании рис и человеческую жизнь, что находит выражение в самых разных аспектах их мировоззрения и поведения. Возделывание риса наложило отпечаток на всю культуру и характер государственности, определило особенности социально-экономического строя стран производителей и потребителей риса, о чем написано немало исследований $[1,4,6,11,21]$. У всех народов Индонезии существуют разные способы ведения рисового хозяйства, такие как обработка поля, посев, жатва, а также особые ритуалы, сопровождающие культивирование риса. Ниже будут кратко описаны практические действия по возделыванию риса у батаков, в которых выражены особое его почитание и особая мифология и которые во многих своих аспектах воплощают специфические формы освоения окружающей среды и восприятия мира этого народа.

Батаки возделывают рис на суходольных и на заливных или искусственно орошаемых полях. На суходольных полях, расположенных, как правило, в малоплодородных горных районах, распространен так называемый подсечно-огневой способ, состоящий в предварительном очищении участка от деревьев и кустарников и их последующего сжигания. В освободившемся пространстве палкой делают ямки, в которые бросают рисовые зерна. Через несколько месяцев снимают урожай. При таком способе выращивания риса почва через определенное время истощается, и приходится осваивать новые участки для дальнейшего возделывания риса.

На заливных полях, расположенных в наиболее плодородных областях вокруг озера Тоба, зерна риса сеют не сразу на поле, а сначала в специальные грядки или высаживают в особый грунт, а затем, примерно через 35 дней, рисовые побеги пересаживают на поле. До цветения рис несколько раз пропалывают. Примерно через 120 дней после пересадки рис созревает, и можно начинать сбор урожая [13, с. 504, 521, 602; 19, с. 23-24] (рис. 1).

Весь цикл выращивания риса у батаков, как и у всех народов Индонезии, осуществляют женщины, а мужчины выполняют вспомогательные работы по очистке полей, вспахиванию земли или сооружению оросительной системы. Но руководит обрядами, сопровождающими возделывание риса как суходольным, так и орошаемым способами, специальный жрец. Эти обряды во многом различаются между собой. У батаков каро жрец - знаток обрядов, необходимых для успешного урожая суходольного риса, называется пермангманг. После того как закончились работы по расчистке поля и сжигания кустарников и

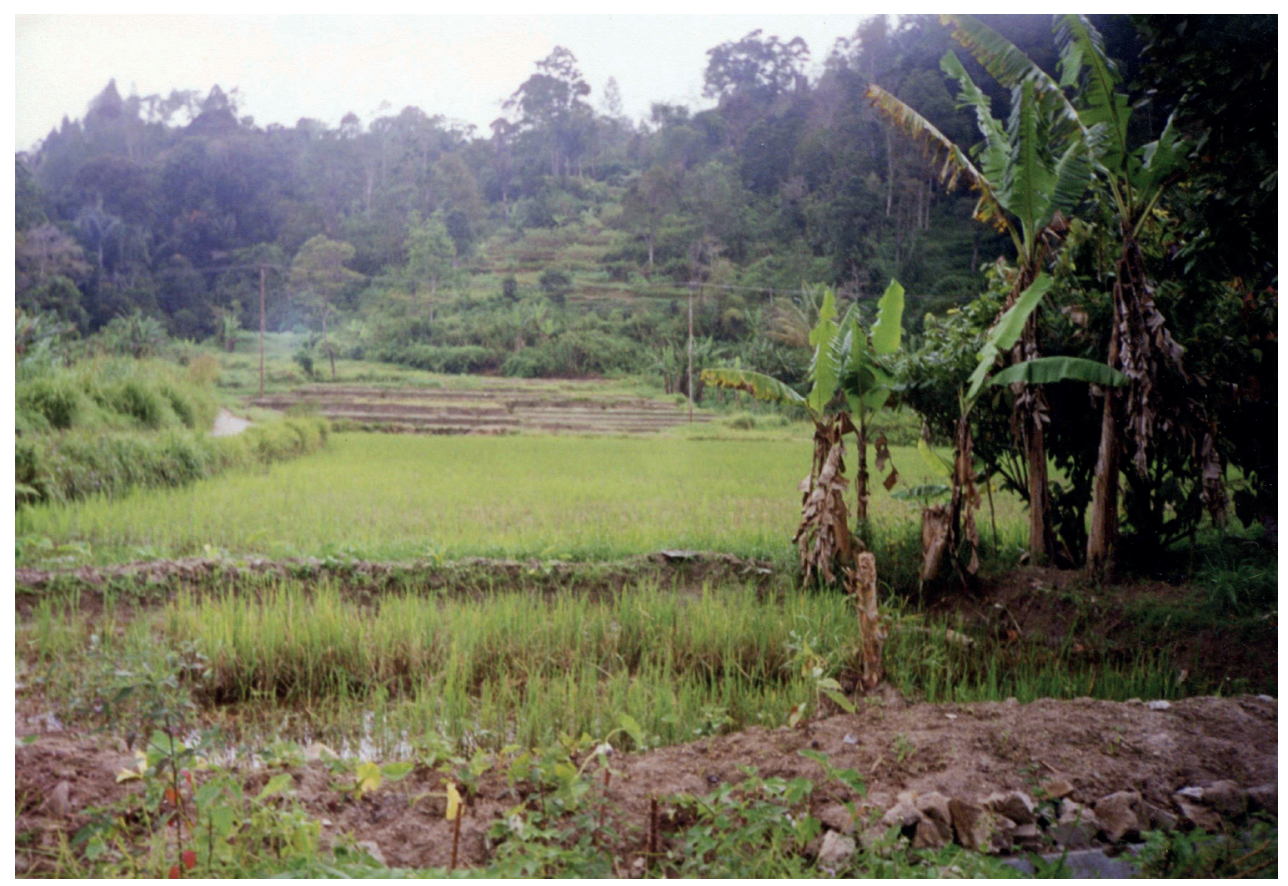

Рис. 1. Заливное рисовое поле у батаков тоба. Фото автора. 
деревьев, жрец просит благословения у божеств. Засевание рисового поля начинается с ритуала: жрец берет палку, обмазанную кровью жертвенного петуха, делает на земле семь ямок и с закрытыми глазами бросает в них рисовые зерна, также обмазанные кровью жертвенного петуха. После этого всякая работа в деревне запрещена в течение четырех дней. Затем табу отменяется, и проходит трапеза, после которой можно продолжать дальнейшие работы. Жрец совершает ритуал рисосеяния на поле каждого жителя деревни, владеющего им.

Когда колосья начинают наливаться зерном, каро «кормят» рис, обращаются с ним как с существом женского пола и называют благоприносящими именами: си Наик - «Поднимающийся» (восклицание при поднесении бетелевой смеси для жевания, с тем чтобы было больше риса) или дают ему имя богини - покровительницы риса - си Даянг, Беру Даянг $[18$, с. 99,$128 ; 17$, с. $161-162 ; 31$, с. 18-19]. Когда женщины у батаков тоба при посеве очищают рис, они должны есть досыта, чтобы зерна тоже наливались сполна. Они должны проводить свое время спокойно, чтобы умиротворить силы природы и отвести от риса злые умыслы врагов и угрозу со стороны птицрисовок и мышей [33, с. 129]. Во время роста и созревания риса ему приносят в жертву несколько видов рыб - денгке порнгис - культовую еду, являющуюся символом физического благополучия человека [30, c. 58]. Как только рис начинает созревать, одна женщина связывает из рисовых стеблей, сжатых в самой высокой части поля, четыре снопа. Считается, что в них содержится тонди - душа риса, которой женщины приносят жертвоприношения [31, с. 19]. После этого можно собирать урожай риса, начало которого осуществляет своими действиями жрец: он срезает горсть рисовых зерен, растирает их до состояния муки и съедает ее на поле вместе с кусками вареного петуха, яйцами и рыбой. Сбор урожая риса заканчивается общим для всей деревни праздником.

Возделывание риса на орошаемых полях сопровождается более подробными и тщательно разработанными ритуалами. Прежде всего, на каждом этапе выращивания этой культуры земледелец тоба (а именно у тоба в наибольшей степени развито заливное рисоводство) постоянно осуществляется связь с предками. Предки, по представлениям этого народа, все время принимают участие в жизни всей общины, продолжая оставаться ее членами. Они существуют в мире мертвых по тем же законам, что существовали в мире живых. Умершие и перешедшие в потусторонний мир предки и живущие в земном мире их потомки неразрывно связаны друг с другом. Предков кормят и ублажают их потомки, которые обращаются к ним за помощью во всех важных жизненных ситуациях [26, с. 191-192; 30, с. 84-89]. Предки основали первые поля, вырыли источники для их орошения, передали их потомкам, и каждое последующее поколение отвечает перед ними за состояние полей. Кроме того, ритуальные действия в течение всего цикла созревания риса (а у батаков он длится около девяти месяцев) обращены помимо предков также к высшему божеству Девата аси-acu, к природным божествам, а также к духу земли, обеспечивающему ее плодородие и представленному в образе ящерицы бораспати ни тано, к женскому божеству нижнего мира в образе змеи, связанной с водной стихией, -
Бору санианг нага [26, с. 48-53]. Перед началом обработки полей совершают действие, называемое «мартуа мома» - счастливое начало. Очищенные рисовые зерна, помещенные в какой-либо сосуд, служащий меркой, с воткнутой веточкой священного дерева баньяна (тоханг-тоханг) несут в благоприятный день на поле. Иногда вставляют еще и тростник - санггар, произнося такие пожелания: «Пусть рис будет так же ветвиться, как эти деревья, и стебель его будет столь же высок и крепок, как у этого дерева». Ветку втыкают в землю на поле и укрепляют белым сырым песком. Затем рисовые зерна преподносят душе (тонди) самого поля и произносят следующее заклинание: «Это мой жертвенный рис (бунти санти-сан$m u)$, жертвенный рис моего поля, да будут удачными полевые работы, да будет плодовит скот, да пройдет благоприносящий дождь (сипандон портаонан), который принесет хороший урожай возделанным полям. Пусть далеко будет война, пусть близко будет счастье и благо, пусть умрут мыши, пусть далеко от середины поля уйдут болезни риса». После этого люди возвращаются в дома и начинается праздничная трапеза, во время которой едят рис, предназначенный для жертвоприношения. Едят также свинину как символ «жирности» полей и рыбу как символ богатства. Трапеза должна происходить в атмосфере согласия между участниками [33, с. 141]. Далее следуют обработка полей, посев рисовых зерен в грунт или специальные грядки, пересадка рассады на поле, наблюдение за созреванием риса, поиски особенно крепких и налитых зернами стеблей, воплощающих «рисового князя» (раджа ни эме), и рисовой души, срезание первых колосьев риса и сбор урожая, заканчивающийся грандиозным праздником, сопровождающимся убиением жертвенного животного, игрой на музыкальных инструментах, танцами, состязаниями, обильной трапезой. Благоприятный момент для начала того или иного действия, связанного с выращиванием риса, определяет жрец. И каждому циклу рисоводства неизменно сопутствуют просьбы, благопожелания и молитвы, обращенные к высшим и природным божествам, рисовой душе, и обильная ритуальная еда, обязательными компонентами которой являются рисовые зерна, мука, пироги, яйца, мясо, рыба и бетелевая смесь для жевания [13, с. 524-529; 31 , с. $20 ; 34$, с. $143-144]$.

Из подробных описаний процесса выращивания риса у батаков может сложиться впечатление, что церемониальные действия, заклинания и благопожелания, произносимые перед началом и завершением сельскохозяйственных работ, а также в период созревания зерна, всякий раз сопровождаемые ритуальной трапезой, занимают значительно больше времени, чем выполнение самих работ, то есть обрядовая сторона возделывания риса важнее практической, утилитарной. На самом деле, все эти действия неотделимы друг от друга, в возделывании риса практическая работа и ценности материального порядка неразрывно связаны с поведением культурно-символического характера. Батакская община в это время функционирует как единый цельный организм, вся деятельность которого направлена на достижение максимально высоких результатов в области освоения окружающей природы - в данном случае для получения достаточного количества риса - одной из главных ценностей жизни, являющейся симво- 
лом самой жизни и обладающей той же социальной и ритуальной значимостью, что и человек. Растущий на полях рис требует постоянной заботы, внимания, бережного к себе отношения, которое сравнивается с внимательным и осторожным отношением к женщине, ожидающей ребенка. До сбора урожая рис считается подобным живому человеку. Срезанный во время урожая рис становится подобен умершему человеку, но возрожденному в новом статусе - в виде зерна. В этой фазе своего существования он уже не требует постоянной заботы, а сам выполняет защитную, охранительную, очистительную функции. Эти его функции раскрываются в многочисленных формах повседневного и ритуального поведения людей, проявляющегося в обрядах жизненного цикла, исцеления, в гаданиях и т. п. [2, с. 49-86].

Отношения между рисом и человеком - это отношения постоянной взаимозависимости и обмена. Человек выращивает рис и таким образом выращивает себя, свой аналог. В сложных, постоянно переплетающихся связях между рисом и человеком, рисом и миром предков, человеком и миром духов рис является центром, вокруг которого совершается вечное круговращение и обмен между природой и обществом. Вот почему, когда батаки говорят, что человек рождается для того, чтобы есть рис [33, с. 47], то, с учетом всего комплекса представлений о человеческой сущности риса, о месте риса в природе и обществе и о разнообразных отношениях между ними, следует понимать это выражение как приобщение ко всей социальной и духовной жизни общины, к преемственности поколений, к ос-

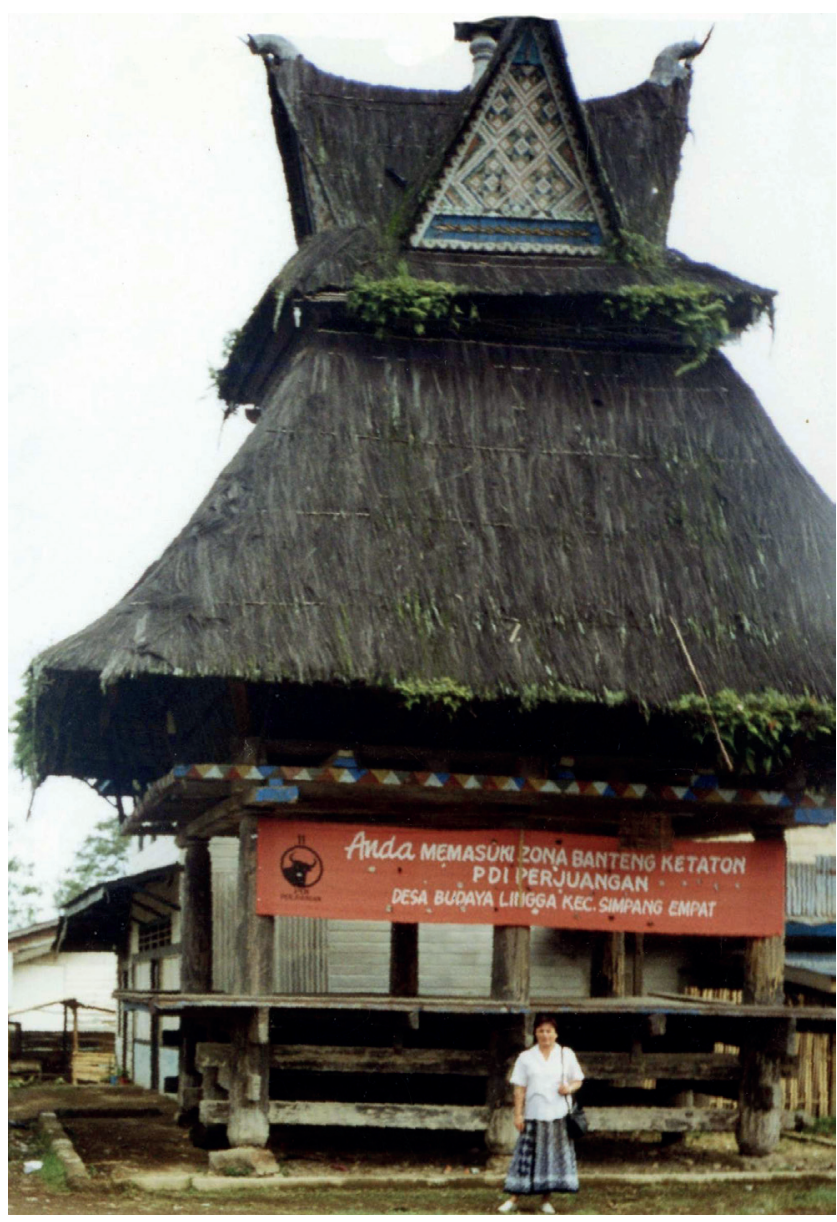

Рис. 2. Старый рисовый амбар в деревне Лингга у батаков каро. Фото автора воению наследия предков, то есть к традиционному укладу жизни во всем ее многообразном проявлении, которая проходит под знаком риса.

\section{Батаки, рисоводство и строительство}

Особую роль у батаков каро играют рисовые амбары. Эта роль далеко не ограничена функцией хранилища собранного урожая риса. По конструкции амбары сходны с наиболее распространенным типом жилых домов. Собранный рис хранится в верхней части амбара. А нижняя часть его является местом ночлега для мальчиков-подростков, неженатых молодых мужчин, гостей мужского пола, а также местом встреч и общения молодежи деревни - юношей и девушек. В этом смысле можно говорить об особой социализирующей роли рисовых амбаров у каро, сходной с мужскими домами у многих народов мира. Раньше в таком амбаре собирался совет старейшин и уважаемых в деревне лиц для обсуждения и решения насущных дел, то есть амбар выполнял общественную функцию дома собраний [25, с. 19-20]. Такой амбар до сих пор сохранился в деревне Лингга, которую автор посетила в 1999 г. (рис. 2), и использовался в новых условиях как место для политической предвыборной агитации. Собранный рис косвенно продолжает «выполнять» свою социальную функцию.

Типологически сходную картину можно наблюдать в практических и символических действиях, связанных со строительством традиционных домов у батаков. Сведения об архитектурных особенностях традиционного батакского жилища и обрядах, свя-

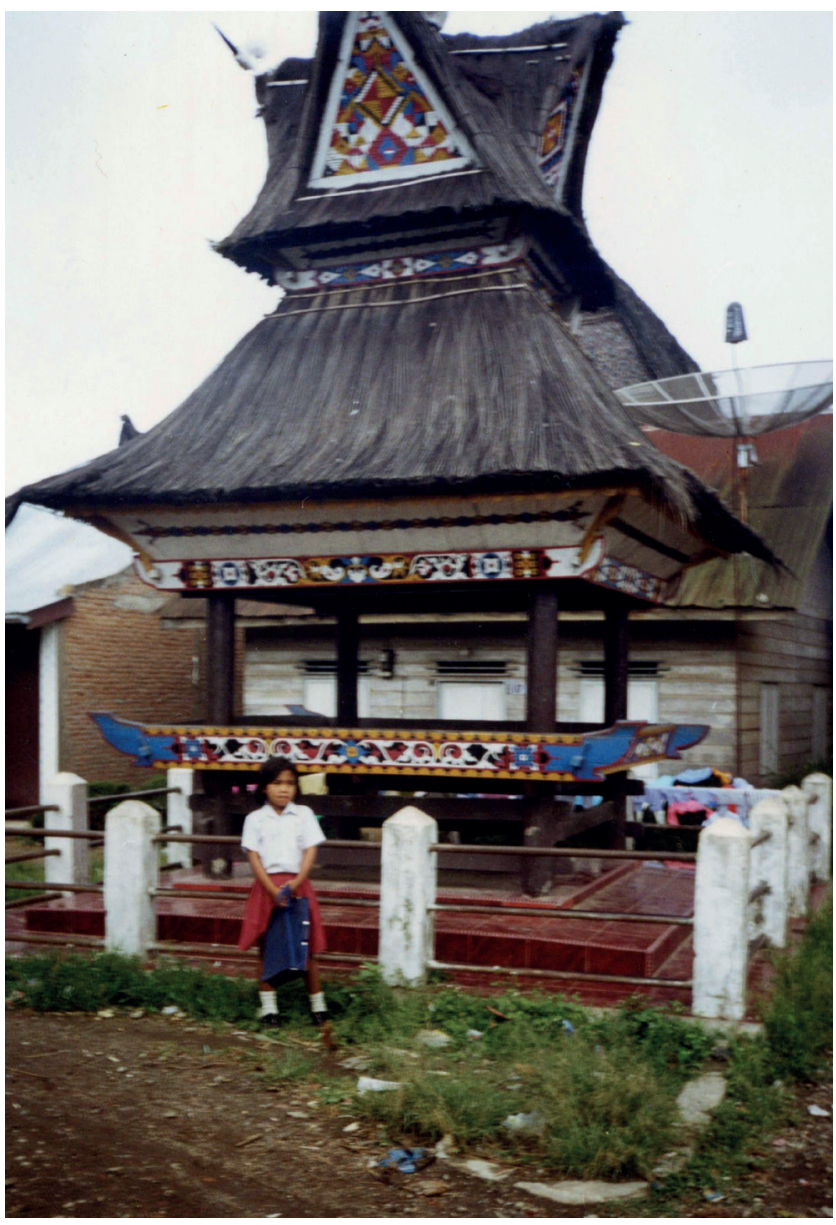

Рис. 3. Традиционный дом у батаков каро. Фото автора 
занных со строительством дома, относятся, в основном, к прошлому веку. Многие из них сейчас находятся в полуразрушенном состоянии, но и в таком виде они продолжают восхищать своей монументальной художественной конструкцией, как и два столетия назад [23, с. 4] (рис. 3). Сейчас традиционных жилищ целиком не строят, но отдельные архитектурные элементы их используют в современных деревянных постройках различного назначения или возводят каменные официальные здания в стиле древней деревянной архитектуры [5, с. 370]. В данном контексте будут рассмотрены традиционные дома каро, которые отличаются от поселений других батакских племен большим разнообразием архитектурных форм и типов построек [24, с. 55].

Батаки каро живут на горном плато высотой 1200 м к северу от оз. Тоба - местности сырой и продуваемой ветрами. Большинство территорий, где они проживают, заняты тропическими лесами, в доли- нах между которыми на большом расстоянии друг от друга расположены деревни с домами людей разного социального статуса - вождей, старейшин и простых общинников, постройки общественного, хозяйственного и культового назначения, такие как общинный дом собраний, амбары для хранения риса, дома для хранения черепов предков, рисорушки и т. п. Образцы таких построек, относящиеся к началу XIX в., но еще сохранившиеся в настоящее время, можно увидеть в Музее антропологии и этнографии им. Петра Великого (Кунсткамера) в Петербурге (рис. 4). Все они схожи по своей конструкции и архитектурному стилю - стоят на сваях, строятся без гвоздей, балки и доски скрепляются между собой путем тщательной подгонки, прилаживания, врезки, связывания бечевкой [28, с. 24-74]. Исследователи отмечали, что форма дома у каро с его очень маленькими и узкими отверстиями для дверей и окон хорошо защищает жителей от неблагоприятных явлений погоды [28,

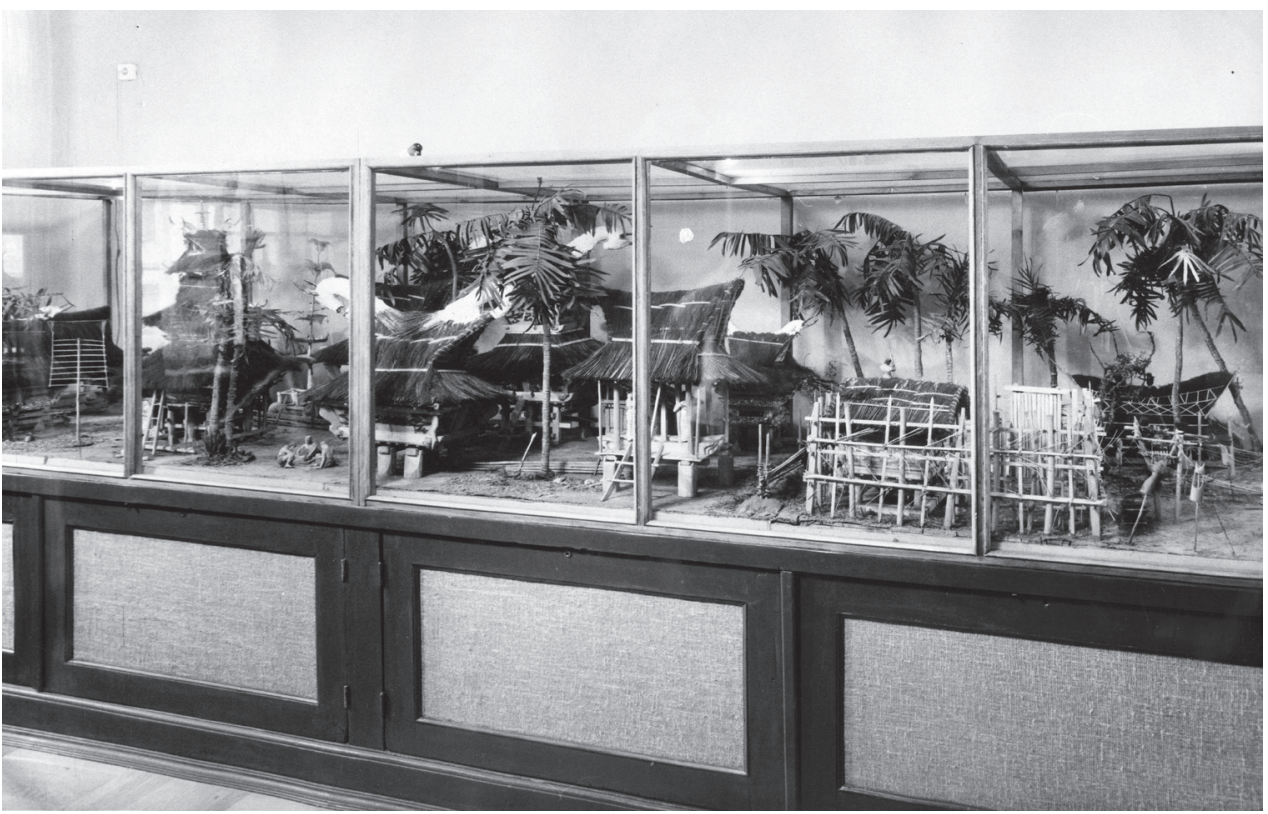

Рис. 4. Макет традиционной деревни батаков каро. Конец XIX в. Кунсткамера. Колл. № 381 L 12

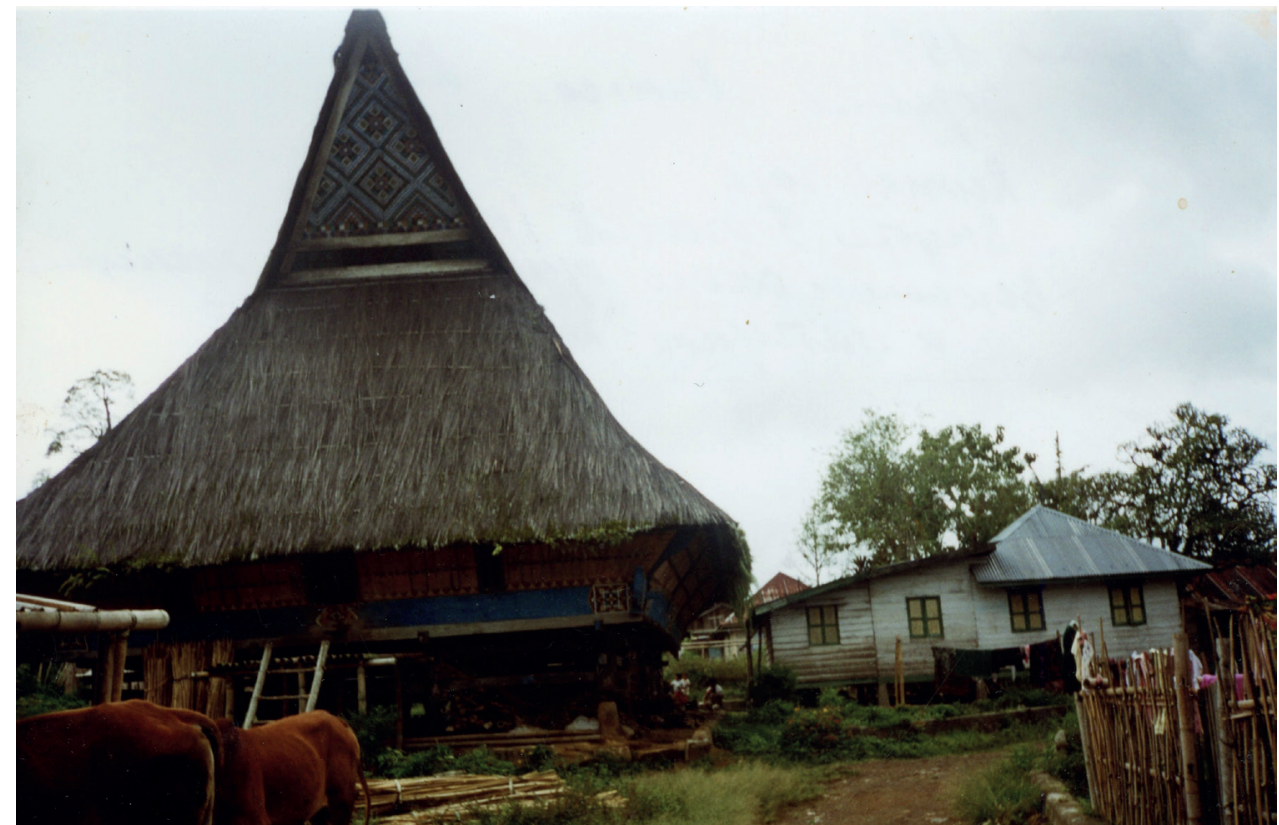

Pис. 5. Конусообразные формы крыш традиционных домов у батаков каро. Фото автора 
c. 34]. Доминирующим конструктивным элементом в архитектуре жилых домов является массивная крутая крыша, покрытая плотным волосяным покровом аренговой пальмы. Двухскатные или четырехскатные крыши имеют разные формы - седловидную, конусообразную, трапециевидную (рис. 5). Именно крышей определяется стиль дома и социальный статус его обитателей $[25$, с. 55$]$. Дома вождей или старейшин выделяются своей пирамидальной многоярусной конструкцией крыши, состоящей из нескольких надстроек, повторяющих в уменьшенных размерах конструкцию основной крыши. Наиболее распространенный тип жилого дома с одной массивной седловидной крышей называется румах сангка манук, эффектная модель которого, сделанная самими каро в конце XIX в., представлена на экспозиции Кунсткамеры (рис. 6).

В жилых домах в зависимости от размеров живут от четырех до двенадцати семей. Чаще всего были распространены дома, предназначенные для восьми семей. Процесс строительства такого дома растягивается на довольно длительное время и состоит из нескольких этапов, включающих выбор подходящего места, определенных видов деревьев, используемых для строительства, подбор работников и т. п.,

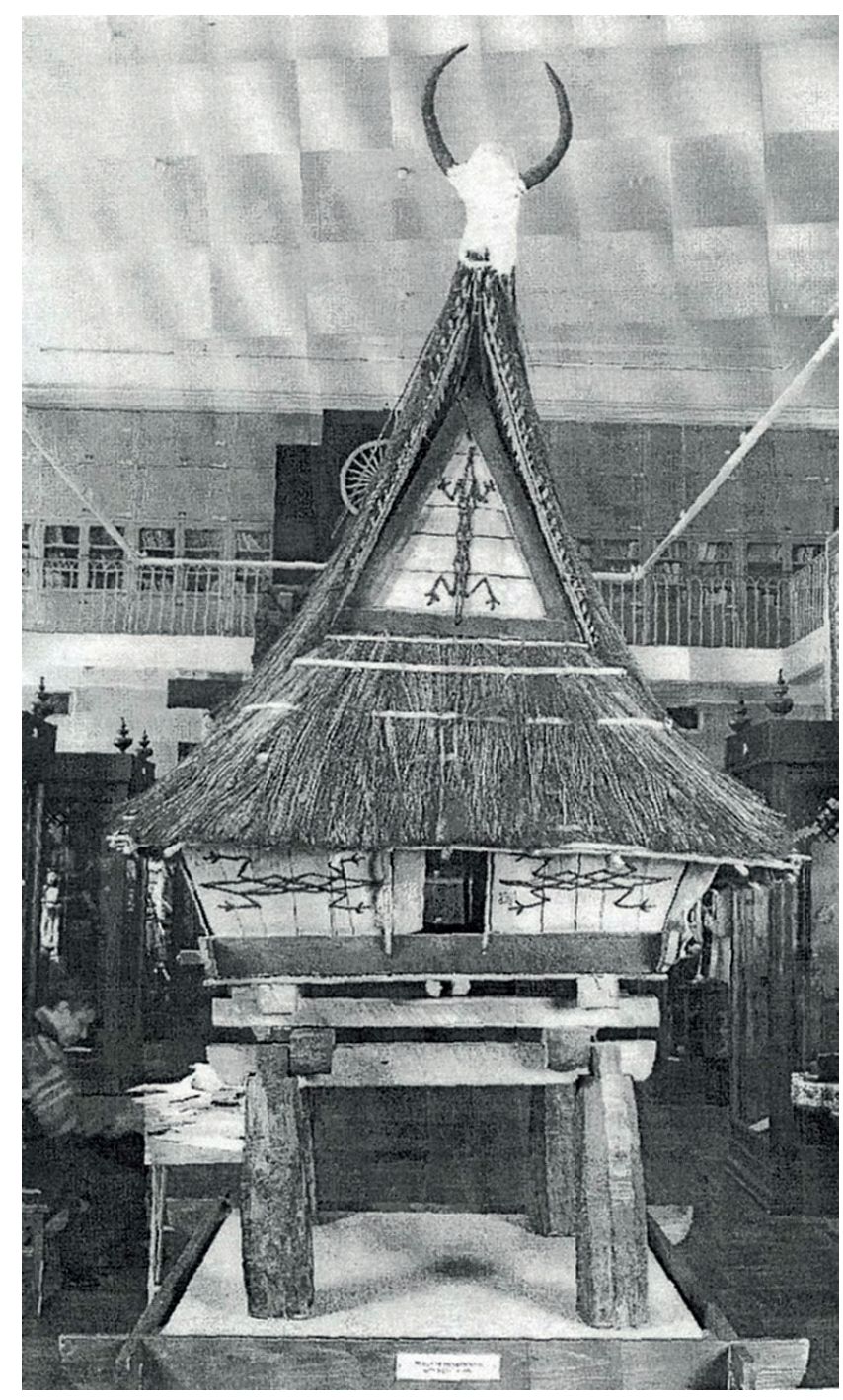

Рис. 6. Модель традиционного дома батаков каро. Конец XIX - начало XX в. Кунсткамера. Колл. № 896-1 причем каждый цикл работ сопровождается определенными ритуальными действиями, длящимися несколько дней [15, с. 511-523]. Сначала в жилище, где проживает будущий хозяин дома (пенгхулу румах), собираются мужчины, подбирают плотников и договариваются о цене. Через некоторое время в том же месте собираются женщины - члены семей будущих жителей нового дома - и торжественно приносят корзину с рисом и небольшую корзинку, где сложено все необходимое для приготовления жевательной смеси из бетеля: сосуд для этой смеси и пучок растений, состоящий из бетеля, гамбира, ветки арековой пальмы с орешком и табака. Со всем этим женщины отправляются на место, где предполагается строительство нового дома. Мужчины расстилают белую циновку, вокруг которой все усаживаются. Из корзинки достают орешек арековой пальмы и кусачками осторожно делят его на две равные части. Вместе с листьями бетеля кусочки орешка кладут на то место, где в будущем доме планируется комната главы семьи или хозяина дома. На бетелевую смесь ставят корзину с рисом, и женщина из рода, давшего жену хозяину дома, держась за края корзины, произносит благопожелания и берет горсть риса. В это время мужчины задумывают, какое должно быть число рисовых зерен в горсти. После тщательного подсчета количества рисовых зерен выясняется, соответствует ли оно задуманному или нет. Если соответствует - это благоприятный знак и означает, что духи содействуют постройке дома. Если результат подсчета рисовых зерен не совпадает с задуманным, всю процедуру повторяют на том же месте. После повторного несоответствия количества рисовых зерен тому, что было предварительно задумано, действо переносится в другое место, находящееся в нескольких метрах от предполагаемого ранее. Процесс продолжается до тех пор, пока не будет достигнут благоприятный результат, необходимый для начала строительства нового дома. Когда желаемый результат, наконец, достигнут, то главы всех присутствующих семей рассыпают вокруг установленного места небольшое количество риса в знак того, что все идет благополучно.

После этого обращаются к жрецу (гуру), чтобы он, пользуясь своими атрибутами, определил, в какой день можно пойти в лес и рубить необходимые для постройки дома деревья. Рано утром в рекомендованный жрецом благоприятный день будущие обитатели дома во главе со старейшим плотником идут в то место, где в доме должна будет находиться комната хозяина дома, и, как и прежде, несут корзину с рисом, корзиночку с бетелевой смесью, куском железа, кусачками, сосудом для извести и связку из семи растений, приносящих, по представлениям каро, счастье и символизирующие богатство, силу, изобилие. Находясь со всем этим в лесу, люди ищут дерево диаметром 6 см, называемое кайю пертабах (буквально «дерево, которое нужно срубить»). Таковым лучше всего считается дерево из пород, называемых на языке каро ндераси, кайю себернаик (сангкетен). Другие породы деревьев использовать нежелательно. Однако есть сведения, что деревья для строительства дома срубаются в разных местах, в том числе и в тех, где обитают злые духи. В этом случае против них применяются защитные меры. Карл Машмейер, один из выдающихся немецких собирателей предметов куль- 
туры и быта батаков, отметил, что в качестве строительного материала используется дерево джохар, имеющее твердую сердцевину [16, с. 123]. А известная исследовательница типов домов в Юго-Восточной Азии Р. Уотерсон пишет, что во всем этом регионе, в том числе и у каро батаков, для строительства используются твердые породы деревьев, такие как тик, ченгал, железное дерево [28, с. 85].

Когда подходящее дерево найдено, вокруг него тщательно очищается пространство, приготавливаются два вида бетелевой смеси для жевания: одна обычная, другая с добавлением особых ингредиентов - листьев бетеля, смазанных кокосовым маслом и вытяжкой из плодов лимонного дерева, употребляемой обычно для заживления ран после обряда подпиливания и чернения зубов. Затем хозяин будущего дома произносит молитву, чтобы рубка дерева прошла благополучно. Плотник обвязывает руку нитью, принесенной в корзине ранее, примеривается четыре раза и одним ударом срубает дерево. Затем он отрезает верхушку с листьями, оставляет ствол длиной 60 см и сдирает с него кору. Со ствола срезаются остатки ветвей и привязываются к нему пять растений, приносящих удачу. С просьбой о благословении все присутствующие укладывают очищенный ствол срубленного дерева на место, выбранное для строительства дома. Эта балка является главной в жилом пространстве будущего дома. Место у ее основания, то есть там, где были корни растущего дерева, предназначено для семьи главы дома, которая так и называется - «комната у основания дерева» (джабу бена кайю). В противоположном конце, называемом «вершина дерева», то есть там, где была лиственная крона, должна будет жить семья родственников хозяина дома по браку. Это пространство называется соответственно «комната у вершины дерева» (джабу уджунг кайю) $[10$, с. $65 ; 25$, с. 58]. После этого следует ряд действий по изготовлению различных древесных материалов, их подгонке друг к другу.

Каждая фаза строительства отдельных частей дома обязательно сопровождается обращением к жрецу для определения благоприятного дня для того или иного начинания, окроплением строительных досок кровью жертвенного петуха и ритуальной трапезой, необходимыми ингредиентами которой являются рис и куриное мясо. Рабочие дни чередуются долгими перерывами на отдых и празднества. Завершение постройки отмечается грандиозным многодневным праздником с убиением буйвола. Важнейшим ритуалом является освящение нового дома. Ритуал проводит жрец на десятый день лунного календаря. В это время постоянно звучит музыка, состоящая из 48 мелодий. Жильцы нового дома во главе с теми, кто займет комнаты у опорной балки - у ее основания и вершины, - в ритуальных одеждах поднимаются по лестнице, у порога их встречает жрец с чашей со специальным снадобьем, нейтрализующим неблагоприятное воздействие злых духов. Оно состоит из смеси рисовой муки, воды и нескольких видов лекарственных растений. Этим снадобьем жрец смазывает лоб и щеки всем входящим в новое жилище. Построенный с соблюдением всех правил и ритуалов дом считается обладающим жизненной силой или душой, то есть живым. Именно так назвала свое фундаментальное этнологическое исследование типов домов Юго-Восточной Азии Р. Уотерсон - «Живой дом» [28].
Таким образом, строительство дома у батаков - в равной мере технологический процесс и ритуальное действо, благодаря которому создается жизненная сила самого дома и благополучное существование его будущих обитателей [28, с. 129].

Следует отметить уподобление внутреннего жилого пространства в традиционном доме батаков каро окружающему природному ландшафту, что находит метафорическое выражение в соответствующих географических терминах. Внутри дом делится на две половины, между которыми проходит желоб, находящийся на двадцать сантиментов ниже уровня пола. Этот своеобразный коридор или проход называют далан лау («путь реки») [25, с. 58] или анак лау («приток реки») [12, с. 12]. Пол одной половины возвышается от стен к центру и называется «гора» (гунунг). Это наиболее почетная часть дома. Пол другой половины от стен снижается. Эта часть дома называется «заливное поле» (caваx) и является менее почетной. Таким образом, сам дом является отражением привычного ландшафта и в этом отношении представляет собой модель окружающего мира $[12$, с. $2 ; 22$, c. $3 ; 28$, с. 94$]$.

\section{Символы природы в декоративных элементах традиционного жилища батаков}

Приведенные выше краткие описания хозяйственной и строительной деятельности батаков северозападной Индонезии являются примером того, как народ, жизнь и благополучие которого зависит от окружающей природной среды, использует комплекс практических рациональных и иррациональных действий культурно-символического и религиозного характера, которые, с одной стороны, направлены на достижение жизненно важных средств пропитания и проживания, а с другой стороны - на сохранение природных богатств, которые являются источником их благополучного существования.

Информация подобного рода заключена не только в реальных действиях, но в той или иной форме присутствует в декоративных элементах традиционного жилища. Рассмотрим только три образа в художественной системе дома каро - буйвола, ящерицы и змеи.

Как уже упоминалось, многие батакские дома имеют седловидную, слегка прогнутую по верху форму крыши, напоминающую очертания головы буйвола, что особенно четко выражено у батаков тоба. Кроме того, у батаков каро скульптурные изображения голов буйвола увенчивают коньки крыш с двух противоположных сторон дома (рис. 4, 6). Они делаются из волосяного покрова аренговой пальмы и обмазываются смесью извести, клея и меда, что защищает их от воздействия дождей и ветров [15, с. 522]. Прикрепление голов буйвола также сопровождается ритуалом под названием мере тандок («питание рогов»). Гуру мбелин - жрец высокого ранга - дает ритуальную еду скульптурным изображениям голов буйвола, состоящую из сырых потрохов красного петуха с солью и жгучим перцем, для того чтобы умиротворить злых духов. Иногда буйволам предлагают воду в горшочке, который подвешивается на шею $[25$, с. $56 ; 10$, c. 89].

Р. Уотерсон считает, что у батаков каро головы буйволов на фронтоне традиционных домов выполня- 
ют защитную функцию [28, с. 7]. Это, конечно, так и есть, но при этом надо иметь в виду, что в этой функции находит свое выражение целый комплекс представлений, связанный с буйволом, который постоянно проявляется в повседневной и в ритуальной жизни батаков. Чтобы понять смысл этого архитектурного элемента, необходимо осветить хотя бы некоторые из них. В данном случае речь идет о представлениях, распространенных среди батаков как у каро, так и у тоба.

У батаков буйвол используется как ездовое, пахотное и культовое животное. Обычная картина деревенской жизни батаков: на дорогах постоянно встречаются повозки, запряженные буйволами (рис. 7), а на рисовом поле буйволы поедают оставшиеся после сбора урожая стебли риса, одновременно вспахивая поле для будущего посева. С буйволом батаки связывают и родственные отношения. Некоторые батакские роды считали себя потомками белого буйвола [32, I: c. 536]. На одном из главных атрибутов батакского жреца - жезле часто встречаются изображения человека с телом буйвола, означающее, возможно, одновременно и человека, и его животного предка, в которого попадает душа человека после смерти [32, IV: c. 115; 3, с. 197]. В прошлом были широко распространены жертвоприношения буйвола, гадания по буйволу, о которых подробно говорится в жреческих книгах, заключение дружественных союзов путем поедания мяса буйвола. Ритуалы, связанные с жертвоприношениями буйвола, часто проводились во время стихийных бедствий. По поведению умирающего животного жрец определял, насколько благосклонно настроены духи предков, высшее божество и властелины восьми сторон горизонта [18, с. 35-41; 27 , с. $238-248 ; 2$, с. $242 ; 5$, с. 255,271$]$. В современной жизни тоба сохранился обряд забивания буйвола для поминальной еды, приготовлению которой автор была свидетелем в 1999 г. (рис. 8).

У каро декоративные элементы жилища, связанные с буйволом, получили, может быть, наиболее яркое воплощение в виде зримых скульптурных изображений. Но в целом реалистические или условные изо- бражения рогов буйвола являются обязательным формообразующим элементом крыши в жилищах всей Индонезии и островов Океании. Более того, они встречаются в Юго-Восточной Азии - как материковой, так и островной, а также в Японии и Китае. Эти изображения могут быть очень разнообразными - от обладающих тонкой и искусной резьбой, в которых отчетливо проглядываются еще и образы змеи или птицы, до просто сложенных крестом деревянных палочек. И очень часто названия этих изображений восходят к слову «рога». И если для многих специалистов - этнологов, археологов, лингвистов - седловидная форма крыши и декоративные ее элементы в виде рогов буйвола в различных вариантах являются важным показателем древнейших связей австронезийских народов и могут во многом по-новому осветить проблемы их происхождения, $(7 ; 8$, с. $19-43 ; 9 ; 14$, с. 165-221; 28, c. 1-26), то для батаков и других народов Индонезии и шире - Юго-Восточной Азии они в самых разнообразных вариантах отражают огромное значение, которое играл и играет буйвол в жизни этих народов, в ее неразрывной связи с окружающей природой, практической и ритуальной деятельностью.

Еще два типичных декоративных элемента на традиционных домах каро, которые сразу обращают на себя внимание, - это образы ящерицы (рис. 6) и змеи, как бы вышитые на передней и задней стенах жилища бечевкой из пальмового волокна. Оба вида пресмыкающихся играют существенную роль в мировоззрении батаков и являются чрезвычайно распространенными персонажами в мифологии, их изображения часто встречаются на культовых предметах - магических жезлах и в жреческих книгах, фигурках предков, на священных сосудах для снадобий и т. д. Встречаются они и на предметах повседневного употребления - оружии, поясах, домашней утвари. Ящерица, по космологическим представлениям этого народа, является воплощением среднего мира, то есть земли, и божеством плодородия, что было отмечено выше [26, с. 56-70; 3, с. 195]. А змея считается главным божеством нижнего мира, представляющим собой водную стихию. Змея также свя-

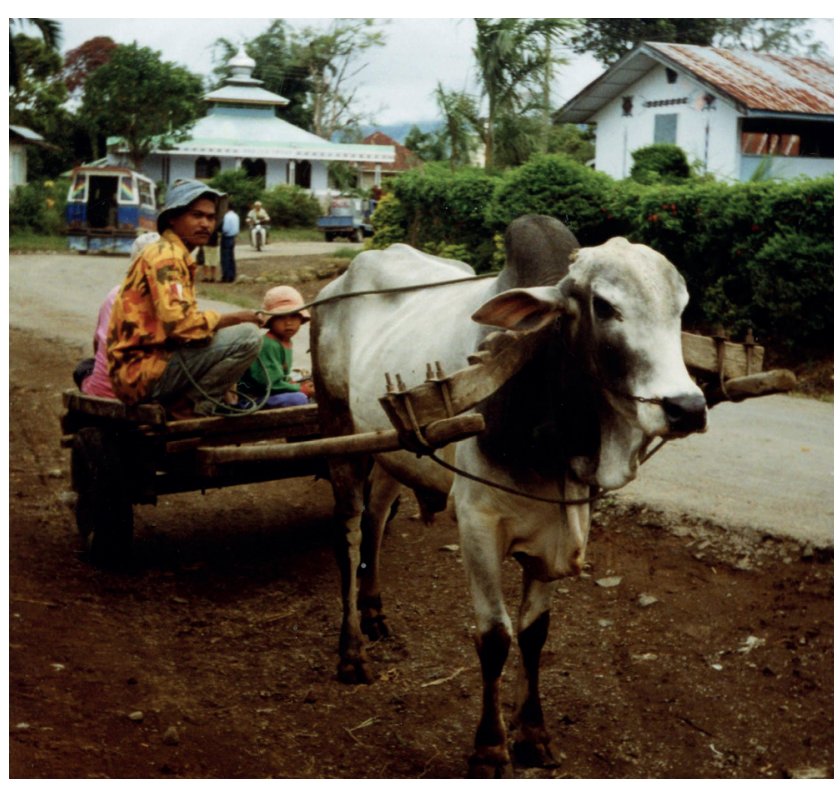

Рис. 7. Повозка с буйволом. Батаки каро. Фото автора

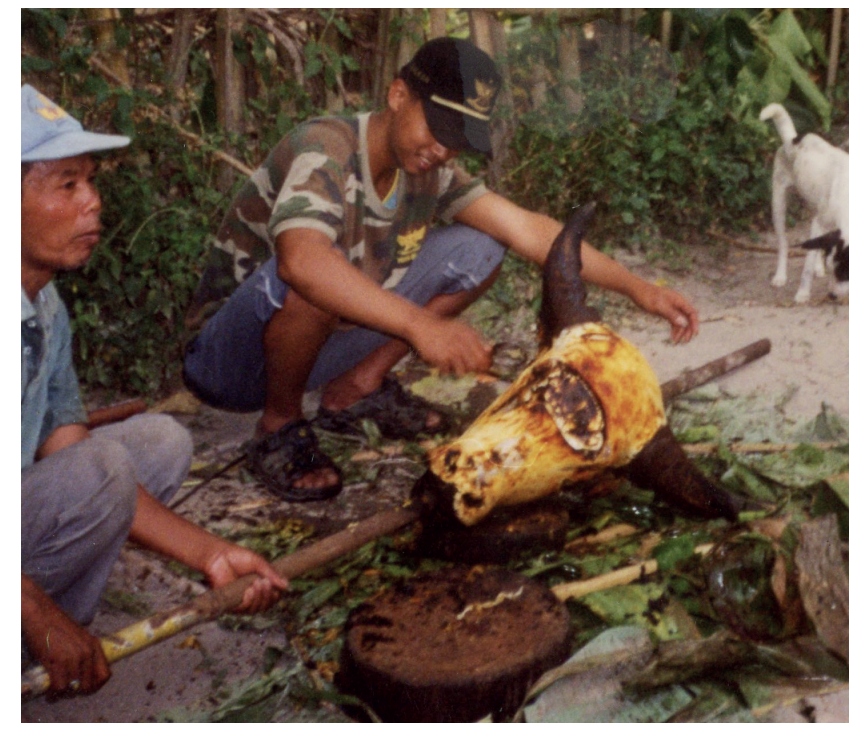

Рис. 8. Разделка буйвола для поминальной трапезы. Батаки тоба. Фото автора 
зана со всей трехчленной структурой мира (с землей, нижним и верхними мирами) и является символом молнии, дождя и воды. Особенно часто встречаются рельефные изображения змеи на жреческих жезлах, а плоскостные - в жреческих книгах [20; 26, с. 53; 2; 3 , c. 195-196]. Изображение змеи дополняет и усиливает космологические представления, связанные с домом у каро батаков, так как само жилище у них, как и у всех народов Индонезии, отражает структуру мира: верхняя часть дома является местом священным, где обитают высшие божества и находятся предметы, составляющие наследие предков, средняя часть является отражением земного мира, где обитает человек, а нижняя часть (как правило, под сваями) является отражением нижнего мира, куда сбрасывается муcop, где содержатся домашние животные и обитают божества низшего уровня [28, с. 93].

\section{Заключение}

Приведенные описания особенностей повседневного и ритуального поведения батаков по отношению к важнейшим традиционным ценностям их жизни рису и дому - выявляет не только восприятие материальных объектов как живых существ, наделенных человеческими и божественными свойствами, но и сложные связи, отношения взаимодействия и обмена между ними, которые можно в широком плане рассматривать как отношения между человеком и природой. Такие отношения удачнее всего можно было бы обозначить термином «партиципация» (сопричастие), предложенным выдающимся этнологом Л. Леви-Брюлем для характеристики свойств архаичного типа сознания, черты которого сохраняются и у вполне современных людей, каковыми являются батаки Суматры.

\section{Литература}

\section{Список русскоязычной литературы}

1. Пейрос ИИ, Шнирельман ВА. Возникновение рисоводства по данным междисциплинарных исследований. В кн.: Лингвистическая реконструкция и древнейшая история Востока. Часть 1. М.: Наука; 1989. с. 179-195.

2. Ревуненкова ЕВ. Книги батакских жрецов в собраниях МАЭ. В кн.: Культура народов Зарубежной Азии и Океании. Л.; 1969. с. 235-56.

3. Ревуненкова ЕВ. Магические жезлы батаков Суматры. В кн.: Культура народов Зарубежной Азии. Л.; 1973. с. 183-200.

4. Ревуненкова ЕВ. Миф-обряд-религия. Некоторые аспекты проблемы на материале народов Индонезии. М.: Наука; 1992.

5. Ревуненкова ЕВ. Индонезия и Малайзия перекресток культур. СПб.: МАЭ РАН; 2010.

6. Чеснов ЯВ. Историческая этнография стран Индокитая. М.: Наука; 1976.

Общий список литературы/Reference List

1. Peyros II, Shnirelman VA. [The emergence of rice growing according to interdisciplinary data]. In: Lingvisticheskaya Rekonstruktsiya i Drevneyshaya Istoriya Vostoka. Chast 2. Moscow: Nauka; 1989. 179-95. (In Russ.)

2. Revunenkova YeV. [Books of Batak priests in the collection the Museum of Anthropology and Ethnography]. In: Kultura Naroodov Zarubezhnoy Azii i Okeanii. Leningrad; 1969. p. 235-56. (In Russ.)

3. Revunenkova YeV. [Magic wands of Batak people of Sumatra]. In: Kultura Narodov Zarubezhnoy Azii. Leningrad, 1973. p. 183-200. (In Russ.)

4. Revunenkova YeV. Mif-Obriad-Religiya. Nekotorye Aspekty Problemy na Materiale Narodov Indonezii. Moscow: Nauka; 1992. (In Russ.)

5. Revunenkova YeV. Indoneziya i Malayziya Perekrestok Kultur. Saint Petersburg: MAE RAN; 2010. (In Russ.)
6. Chesnov YaV. Istoricheskaya Etnografiya Stran Indokitaya. Moscow: Nauka; 1976. (In Russ.)

7. Bellwood P. Prehistory of the Indo-Malaysian Archipelago. New South Wales: North Ryde; 1985.

8. Blust R. Austronesian Culture History: Some Linguistic Inferences and their Relations to the Archaeological Record. Word Archaeology. 1976;8(1):19-43.

9. Domenig G. Tektonik im Primitiven Dachbau. Zürich; 1980.

10. Domenig G. Variation in Karo architecture. In: Schefold R et al., eds. Indonesian Houses. Vol. 2. Survey of Vernacular Architecture in Western Indonesia. Leiden; 2008. p. 49-99.

11. Smith RB, Watson W, eds. Early South East Asia (Essays in Archeology, History and Historical Geography). Oxford: Oxford University Press; 1979.

12. van der Goes B. Kuta: The Karo-Batak village as a cultural construction of its ecological surroundings. Symbolic Meaning in Traditional Habitat. 1992;42:1-36.

13. Hasselt AL. Note betreffende de kennis de rijscultuur in de residentie Tapanuli. Tijdschrift voor Indische Taal, - Land - Volkenkunde. 1893;36:2.

14. Heine-Geldern R. Some tribal art style in South East Asia: An experiment in art history. In: Fraser D, ed. The Many Faces of Primitive Art: A Critical Anthropology. Englewood Cliffs; 1966.

15. Huender W. Het Karo-Bataksche Huis. Bijdragen tot de Taal-, Land- en Volkenkunde (Journal of the Humanities and Social Sciences of Southeast Asia). 1929;85.

16. Joustra M. Karo-Bataksch Woordenboek. Leiden; 1907.

17. Joustra M. Batakspigel. Leiden; 1926.

18. Korn VE. Bataksche offerande. Bijdragen tot de Taal-, Land- en Volkenkunde (Journal of the Humanities and Social Sciences of Southeast Asia). 1953;109:1-2. 
19. Loeb E. Sumatra. Its History and People. Wien; 1935.

20. Pleyte SM. Zur Kenntniss der religiösen Antschauungen der Bataks. Globus. 1894; Bd. 65.

21. Norlund NI, Geredith S, Gerdin I., eds. Rice Societies: Asian Problem and Prospects. Riverdale; 1986.

22. Sargeant G, Saleh R. Traditional Buildings of Indonesia. Vol. 2. Batak Karo. Bandung; 1973.

23. Schefold R, Nas PJ, Wessing M. Introduction. In: Schefold $\mathrm{R}$ et al., eds. Indonesian Houses. Vol. 1. Tradition and Transformation in Vernacular Architecture. Singapore; 2004.

24. Sibeth A. The Batak. Peoples of the Island of Sumatra. New York; 1991.

25. Singrambun M. Kinship, Descent and Alliance among Karo Batak. Berkeley; 1975.
26. Stöhr W, Zoetmulder P. Die Religionen der Indonesiens. Stuttgart; 1965.

27. Voorhoeve P. Bataksche Buffelwichelarij. Bijdragen tot de Taal-, Land- en Volkenkunde (Journal of the Humanities and Social Sciences of Southeast Asia). 1958;114. afl.2.

28. Waterson R. The Living House. An Anthropology of Architecture in South-East Asia. Singarimbun, Oxford, New York; 1991.

29. Warneck J. Die Religion der Batak. Leipzig; 1909.

30. Warneck J. Toba-Batak-Deutsches Wörterbuch. Den Haag; 1977.

31. van der Weijden G. Indonesische Reisritual. Basel; 1981.

32. Wilken GA. De Verspreide Geschriften. Semarang; 1912.

33. Winkler J. Toba-Batak auf Sumatra in Gesunden und Kranken Tagen. Stuttgart; 1925. 